\title{
ANALISIS PENGARUH KOMUNIKASI, BUDAYA ORGANISASI DAN KOMPENSASI TERHADAP KINERJA KARYAWAN PADA PT. IRA WIDYA UTAMA MEDAN
}

\author{
Sahat Simbolon \\ STIE IT\& B Medan Indonesia Jl. Mahoni No.16, Medan, 20235, Indonesia \\ e mail : sahats_simbolon@yahoo.com
}

\begin{abstract}
This study aims to describe the influence of communication, organizational culture and compensation on employee performance at PT. Ira Widya Utama Medan. This research was conducted at PT. Ira Widya Utama Medan which lasted for 3 (three) months, starting from February 2017 until May 2016. This research uses census method. Research respondents are all employees of PT. Ira Widya Utama Medan, amounting to 72 (seventy two) people. The instrument used is a questionnaire to collect data from communication variables, organizational culture and compensation and employee performance variables. Data analysis technique used is validity test, reliability test, descriptive analysis, multicollinearity test, normality test, multiple linear regression analysis, multiple linear correlation coefficient test, partial hypothesis test or $t$ test, simultaneous hypothesis test or F test, and calculation of coefficient of determination. Descriptive analysis results for communication and organizational culture variables are in good category while the compensation and employee performance variables are in the category of good enough PT. Ira Widya Utama Medan. Based on partial analysis, communication, organizational culture and compensation have a positive and significant impact on employee performance at PT. Ira Widya Utama. Based on the simultaneous analysis, communication, organizational culture and compensation have a positive and significant impact on employee performance at PT. Ira-Widya Utama Medan. Contribution from communication variable, organizational culture and compensation to improve employee performance variable at PT. Ira Widya Utama Medan is equal to 0.812 or $81.2 \%$, while the remaining 0.188 or $18.8 \%$ is influenced by other variables not examined by the authors in this study, suchas leadership, work environment, workmotivation, competence, workcommitment and othesetc.
\end{abstract}

Keywords: Communication, Organizational Culture, Compensation and Performance

\section{PENDAHULUAN}

Manajemen memiliki tiga dimensi, yaitu sumber daya, pengelolaan dan tujuan. Berbagai sumber daya yang ada harus direncanakan dengan baik, diorganisasikan, digerakkan, dan diawasi sehingga penggunaannya tepat sebagaimana rencana yang ditetapkan. Ketersediaan sumber daya manusia yang melimpah kurang berguna jika tidak dapat dikelola dengan baik oleh manusia. Untuk itulah organisasi dituntut untuk merencanakan dan mengembangkan kualitas sumber daya manusia dengan terusmenerus.Sumber daya manusia dalam setiap organisasi baik publik maupun bisnis, adalah sumber daya yang utama, disamping berbagai sumber daya-sumber daya lainnya. Hal ini diakibatkan manusia menjadi pelaku utama yang akan menggerakkan berbagai sumber daya tersebut. Oleh sebab itu, dalam mengelola berbagai sumber daya tersebut, sumber daya manusianya haruslah berkualitas.

Kegiatan di bidang sumber daya manusia dapat dilihat dari dua sudut pandang, yaitu dari sisi pekerjaan dan sisi pekerja. Dari sisi pekerjaan terdiri dari analisis dan evaluasi pekerjaan. Sementara dari sisi pekerja meliputi kegiatan-kegiatan pengadaan tenaga kerja, penilaian prestasi kerja, pelatihan dan pengembangan, promosi, kompensasi dan pemutusan hubungan kerja.Sumber daya manusia harus siap, mau dan mampu memberikan sumbangan atau kontribusi terhadap pencapaian tujuan organisasi. Tujuan sumber daya manusia adalah 
untuk meningkatkan kontribusi produktif orang-orang yang ada dalam organisasi melalui sejumlah cara yang bertanggung jawab secara strategis, etis, dan sosial.

Setiap perusahaan yang ingin terus berkembang harus memperhatikan faktor-faktor sumber daya yang dimilikinya, diantaranya adalah faktor sumber daya manusia. Oleh karenanya, pemanfaatan sumber daya manusia harus diperlakukan dengan baik agar pekerja dapat bekerja dengan efektif, efisien dan mempunyai kinerja yang tinggi. Berbagai faktor yang mempengaruhi kinerja pekerja diantaranya adalah faktor komunikasi, etos kerja, motivasi kerja, komitmen organisasi, kompetensi, kompensasi dan kepuasan kerja yang ada di dalam suatu perusahaan.

Dalam lingkungan bisnis global saat ini, keberhasilan bisnis sangat tergantung pada kemampuan organisasi untuk mengelola secara efektif armada kerja yang berbeda-beda. Keberhasilan manajemen armada kerja yang beraneka ragam menuntut perusahaan untuk menjalankan komunikasi produktif, yang bertujuan membangkitkan suatu harmoni dalam lingkungan pegawai.

Komunikasi merupakan sesuatu yang baku, sudah pasti terjadi dalam menjalankan organisasi, namun komunikasi efektif belum tentu terlaksana. Proses komunikasi melibatkan lima unsur penting yaitu orang yang menyampaikan pesan, pesan yang dikomunikasikan, media penyampaian, penerima pesan, dan umpan balik. Dalam hal ini siapa yang, mengatakan apa, dengan cara apa, kepada siapa dan dengan dampak apa, maka kita perlu mengatahui cara terjadinya komunikasi.

Pimpinan atau atasan dapat mempengaruhi atau memberi contoh kepada pengikutpengikutnya melalui proses komunikasi dalam upaya mencapai tujuan organisasi. Dalam tercapainya kerjasama yang harmonis antara pemimpin dan bawahannya maka komunikasi antar sesama sangatlah penting dan perlu dijaga dengan baik pula.Komunikasi sebuah organisasi seharusnya memungkinkan terjadinya komunikasi dalam empat arah yang berbeda yaitu komunikasi ke bawah, komunikais ke atas, komunikasi horizontal, dan komunikasi diagonal. Karena arah-arah komunikasi ini menghasilkan kerangka untuk terjadinya komunikasi organisasi yang efektif dan cara-cara untuk mengatasinya.

Dalam lingkungan organisasi komunikasi sangatlah diperlukan untuk memberikan informasi terhadap prosedur-prosedur dan cara kerja sistem dalam pelaksanaan kegiatan organisasi dari atasan ke bawahannya. Seorang pemimpin yang memiliki wawasan pemimpin yang tinggi dan pengalaman kerja yang handal pada suatu bidang tetapi tidak memiliki komunikasi yang lancar terhadap bawahannya maka dalam pencapaian tujuan dalam suatu organisasi pun tidak akan maksimal. Oleh sebab itu antara pemimpin dan bawahan perlulah menjalin hubungan komunikasi yang baik.Dengan adanya jalinan hubungan komunikasi yang bagus maka interaksi antara pimpinan dan karyawan pun akan terjalin dengan bagus pula sehingga dalam penyampaian informasi-informasi dalam organisasi pun dapat berjalan dengan lancar. Dengan komunikasi yang bagus maka keterbukaan ide-ide pemikiran antar atasan dan bawahan dapat lebih baik dimana bilamana adanya ketidakseragaman diantara keduanya dalam prosedur sistem organisasi maka dapat didiskusikan untuk mencari solusi pemecahannya sehingga tidak ada kesalahpahaman yang berkelanjutan.

Penggunaan istilah budaya organisasi dengan mengacu pada budaya yang berlaku, bukan saja pada perusahaan akan tetapi berlaku juga pada pendidikan karena pada umumnya pendidikan itu dalam bentuk organisasi, yaitu bekerja sama antara beberapa orang yang membentuk kelompok atau satuan kerja sama tersendiri.Dalam budaya organisasi terjadi sosialisasi nilai-nilai dan menginternalkan dalam diri para anggota, menjiwai orang per orang di dalam organisasi. Dengan demikian, maka budaya organisasi merupakan jiwa organisasi dan jiwa anggota organisasi sehingga tidak dapat dipisahkan karena telah menyatu di dalam diri seseorang dan menjadi perilaku para anggota organisasi.

Budaya organisasi berperan penting, karena akan merubah sikap dan perilaku sumber daya manusia untuk mencapai kinerja yang tinggi dalam menghadapi tantangan masa depan. Analisis Pengaruh Komunikasi, Budaya Organisasi dan Kompensasi Terhadap Kinerja Karyawan 28 pada PT. Ira Widya Utama Medan. Oleh : Sahat Simbolon 
Menurut Henry (2012) budaya organisasi pada dasarnya merupakan "apa yang dirasakan, diyakini, dan dijalani" oleh sebuah organisasi. Budaya organisasi merupakan faktor yang akan menentukan bagaimana tujuan dapat dicapai secara efektif dan efisien.Dalam suatu organisasi atau perusahaan yang budaya organisasinya kuat, nilai-nilai kebersamaan di pahami secara mendalam, dianut, dan diperjuangkan oleh sebagian besar para anggota organisasi yang kuat dan positif sangat berpengaruh terhadap perilaku dan kinerja karyawan.

Secara spesifik budaya organisasi padaPT. Ira Widya Utama Medan akan ditentukan oleh kondisi team work (kerja tim), leaders (pemimpin), characteristics of organization (karakteristik organisasi), serta administration process (proses administrasi) yang berlaku. Budaya organisasi berperan penting, karena akan merubah sikap dan perilaku sumber daya manusia untuk mencapai produktivitas yang tinggi dalam menghadapi tantangan masa depan. Karyawan bukan sekadar aset utama organisasi, tetapi merupakan modal manusia yang memiliki peran sangat menentukan bagi kemajuan sebuah organisasi, karena karyawan menjadi penggerak seluruh aktivitas organisasi. Seluruh aktivitas manajemen sumber daya manusia, yang diantaranya adalah pemberian kompensasi yang bertujuan untuk menyediakan tenaga kerja yang berkinerja unggul sesuai tugas masing-masing sehingga mampu memberikan kontribusi terbaik bagi organisasi.

Hubungan antara organisasi dengan karyawan merupakan suatu kerja sama dalam kontrak psikologis, yaitu masing-masing pihak memiliki hak dan kewajiban yang telah disepakati bersama. Organisasi memiliki hak untuk memperoleh kewajiban tertentu dari karyawan melalui pelaksanaan pekerjaan dalam organisasi. Namun organisasi memiliki kewajiban untuk menghargai kontribusi karyawan dengan sejumlah imbalan atau kompensasi. Kompensasi yang diberikan kepada karyawan dapat bersifat finasial maupun non finasial yang diperlukan oelh karyawan untuk memenuhi kebutuhan hidupnya dan untuk mendukung palaksanaan pekerjaanya.Pemberian kompensasi kepada karyawan harus terencana dengan baik, terintegrasi dan komprehensif agar mampu mendorong semangat kerja yang tinggi sehingga kinerja karyawan akan meningkat.

Kinerja karyawan dapat ditingkatkan melalui peningkatan budaya organisasi dan kompensasi, karena dengan budaya organisasi dan kompensasi yang diberikan perusahaan kepada karyawan, semangat, kemauan, dan ketelitian karyawan ada saat bekerja akan lebih maksimal, fokus, dan disiplin. Pemberian kompensasioleh perusahaan dapat dalam bentuk uang atau barang untuk memenuhi berbagai kebutuhan mereka. Kompensasi yang akan diterima oleh mereka merupakan cermin dari apa yang telah mereka berikan atau kerjakan kepada organisasi atau perusahaan.Pemberian kompensasi yang dilaksanakan secara benar dan memuaskan akan mendorong karyawan untuk bekerja lebih baik dalam mencapai tujuan organisasi atau perusahaan.

Kompensasi yang tidak sesuai dengan kinerja karyawan sering menyebabkan karyawan, sebagai manusia tidak merasa puas, tidak betah dan memutuskan untuk mencari yang lebih baik lagi. Dengan adanya persaingan antar perusahaan yang semakin meningkat dapat mempengaruhi para karyawan yang merasa tidak puas dalam satu perusahaan akan berpindah ke perusahaan lainnya sesuai keputusan ekonomi. Oleh karena itu pemberian kompensasi yang adil dan benar sangat berpengaruh terhadap kinerja pegawai, karena dalam memberikan kompensasi yang adil dan benar akan meningkatkan kinerjakaryawan untuk menyelesaikan pekerjaan dengan tepat waktu.

PT. Ira Widya Utama Medan merupakan salah satu perusahaan yang bergerak dibidang Real Estate, jasa kontraktor dan perkebunan. Pada PT. Ira Widya Utama Medansudah merupakan budaya organisasi bagi karyawan untuk melaksanakan ibadah/sholat, menciptakan suasana santai dengan mengadakan acara rekreasi bersama di objek-objek wisata yang ada di Sumatera Utara, menyediakan fasilitas berupa kantin dan tempat parkir kendaraan karyawan. 
Pemberian kompensasi kepada karyawan dapat berupa gaji, tunjangan insentif, kenaikan skala gaji. Sistem penggajian pada PT. Ira Widya Utama Medan belum sesuai dengan harapan para karyawan. Tunjangan insentif yang diberikan kepada karyawan juga tidak sesuai dengan kinerja karyawan pada perusahaan.Dari uraian tersebut, penulis tertarik melakukan penelitian dengan judul: "Analisis Pengaruh Kompunikasi, Budaya Organisasi dan Kompensasi Terhadap Kinerja Karyawan Pada PT. Ira Widya Utama Medan“.

Berdasarkan identifikasi masalah, dirumuskan masalah penelitian adalah:

1. Bagaimana pelaksanaan komunikasi, budaya organisasi, kompensasi dan kinerja karyawan pada PT. Ira Widya Utama Medan?

2. Apakah komunikasimempunyai pengaruh yang positif dan signifikan terhadap kinerja karyawan pada PT. Ira Widya Utama Medan?

3. Apakah budaya organisasi mempunyai pengaruh yang positif dan signifikan terhadap kinerja karyawan pada PT. Ira Widya Utama Medan?

4. Apakah kompensasimempunyai pengaruh yang positif dan signifikan terhadap kinerja karyawan pada PT. Ira Widya Utama Medan?

5. Apakah komunikasi, budaya organisasi dan kompensasimempunyai pengaruh yang positif dan signifikan terhadap kinerja karyawan pada PT. Ira Widya Utama Medan?

Tujuan penelitian adalah untuk mengetahui, menganalisis, dan mengkaji :

1. Pelaksanaan komunikasi, budaya organisasi, kompensasi, dan kinerja karyawanpadaPT. Ira Widya Utama Medan.

2. Pengaruh komunikasi terhadap kinerja karyawanpada PT. Ira Widya Utama Medan.

3. Pengaruh budaya organisasi terhadap kinerja karyawanpada PT. Ira Widya Utama Medan.

4. Pengaruh kompensasi terhadap kinerja karyawanpada PT. Ira Widya Utama Medan.

5. Pengaruh budaya organisasi dan kompensasi terhadap kinerja karyawanpada PT. Ira Widya Utama Medan.

Manfaat penelitian adalah:

1. Bagi organisasi, memberikan bahan informasi kepada pimpinan mengenai pengaruh komunikasi,budaya organisasidan kompensasi terhadap kinerja karyawan.

2. Menambah pengetahuan penulis mengenai pengaruh komunikasi, budaya organisasi, dan kompensasi terhadap kinerja karyawan.

3. Bagi peneliti lain, dapat dijadikan sebagai bahan referensi dalam melakukan penelitian selanjutnya.

\section{TINJAUAN PUSTAKA}

\section{A. Pengertian Komunikasi}

Menurut Frances G. Chandle dalam bukunya Manullang (2014 :253) komunikasi adalah proses pertukaran pikiran, perasaan dan informasi. Menurut Bangun (2016:358) komunikasi adalah proses bertukar informasi dan penertian antar beberapa individu melalui sistem, simbol, dan perilaku. Sementara Luthans (2011:70), komunikasi adalah proses yang diperlukan oleh manajemen melakukan fungsinya, perencanaan, organizing, leading, dan controlling dapat tercapainya melalui proses komunikasi memungkinkan manajer menemban tanggung jawab yang dilimpahkan perusahaan padanya.Fungsi komunikasi dalam organisasi merupakan sarana untuk memadukan tugas-tugas yang terorganisasi. Menurut Bangun (2012 : 361) mengemukakan empat fungsi komunikasi dalam suatu organisasi, yaitu sebagai pengawasan, motivasi, pengungkapan emosi, dan informasi.

Komunikasi merupakan penyampaian pesan yang disampaikan oleh pengirim ke penerima pesan melalui media komunikasi yang tepat. Menurut James AF. Stoner dalam bukunya Manullang (2014:254) proses komunikasi dalam penyampaian pesan, pengirim menyampaikan pesan ke penerima pesan melalui beberapa tahap antara lain : pengirim mempunyai ide, pengkodean ide, penyampaian pesan melalui media komunikasi, penerimaan 
pesan, penafsiran pesan, dan umpan balik. Tahapan-tahapan penyampaian pesan ini merupakan proses komunikasi. Dalam proses komunikasi tersebut, yang paling diharapkan oleh penyampai pesan di sini adalah adanya umpan balik atas pesan yang disampaikannya kepada penerima pesan. Dengan adanya umpan balik berarti pesan yang disampaikan oleh pengirim pesan dapat dipahami dengan baik dan menarik bagi si penerima pesan, karena inilah yang merupakan tujuan dari komunikasi.

Menurut Bangun (2012 : 364) bentuk-bentuk komunikasi terdiri dari : komunikasi tertulis, komunikasi lisan, komunikasi non verbal, komunikasi antarpribadi,dan komunikasi lintas budaya.

\section{B. Pengertian Budaya Organisasi}

Robbins dalam bukunya Torang (2014 : 106) berpendapat bahwa budaya oraganisasi merupakan suatu sistem dari makna organisasi/arti bersama yang dianut dari para anggotanya yang membedakan organisasi dari organisasi lainnya. Sistem makna bersama tersebut merupakan seperangkat karakteristik utama yang dihargai oleh organisasi tersebut.Budaya organisasi dapat juga dikatakan sebagai kebiasaan yang terus berulang-ulang dan menjadi nilai dan gaya hidup oleh sekelompok individu dalam organisasi yang diikuti oleh individu berikutnya. Oleh sebab itu budaya organisasi merupakan dasar bagi pimpinan dan staf/anggota organisasi dalam membuat perencanaan atau strategi dan taktik dalam menyusun visi-misi untuk mencapai tujuan organisasi.

Cummings dalam bukunya Torang (2014 : 107) membagi empat hirarki budaya organisasi, antara lain ; (1) basic assumptions (berada di bawah alam sadar; (2) velues (kepedulian); (3) norma (panduan individu dalam organisasi); (4) artifacts (wujud konkrit : sistem, prosedur, struktur dan aspek fisik organisasi).

Untuk menjadikan budaya organisasi yang kuat dalam suatu organsiasi ditentukan oleh dua faktor utama, yaitu : (1) penyebaran nilai-nilai budaya yang lebih efektif dijalankan dengan melakukan orientasi tugas dan penghargaan atas prestasi kerja yang dicapai sumber daya manusia sehingga seluruh sumber daya manusia yang ada di organisasi mengetahui secara jelas nilai-nilai yang berada dalam organisasi tersebut, (2) tingkat komitmen organisasional anggota terhadap nilai-nilai inti yang ada.

Jeff Cartwright dalam bukunya Torang (2014: 107) membagi empat bentuk budaya organisasi yang dipandang sebagai siklus budaya, yaitu :Monoculture, Superordinate Cultur,Divisive Culture, dan Disjunctive Culture.Menurut Robbins dalam Uha (2013 : 235), dari sisi fungsi, budaya organisasi mempunyai beberapa peran dalam organisasi, antara lain: budaya mempunyai suatu peran pembeda, budaya organisasi membawa suatu rasa identitas bagi anggota organisasi, budaya organisasi mempermudah timbulnya komitmen pada sesuatu yang lebih luas daripada kepentingan diri individu dan budaya organisasi meningkatkan kemantapan sistem sosial.

Menurut Robbins dalam Uha (2013 : 238) adapun beberapa karakteristik budaya organisasi, antara lain: inovasi dan pengambilan resiko (innovation and risk taking); perhatian yang rinci (attention to detail) ; orientasi hasil (outcome orientation) ; orientasi pada manusia (people orientation); orientasi tim (team orientation); keagresifan (aggressiveness) ; stabilitas (stability).

\section{Pengertian Kompensasi}

Pemberian kompensasi kepada karyawan harus mempunyai dasar yang logis dan rasional. Kompensasi sangat penting bagi karyawan itu sendiri sebagai individu, karena besarnya kompensasi merupakan pencerminan atau ukuran nilai pekerjaan karyawan itu sendiri. Kompensasi bukan hanya penting untuk para karyawan saja, melainkan juga penting bagi organisasi itu sendiri, karena program-program kompensasi adalah merupakan pencerminan upaya organisasi untuk mempertahankan sumber daya manusia. 
Menurut Sinambela (2016:218) menyatakan bahwa kompensasi adalah pengaturan keseluruhan pemberian balas jasa bagi employers maupun employees, baik yang langsung berupa uang (finansial) maupun yang tidak langsung berupa uang (nonfinansial).Menurut Yani M. (2012:139), kompensasi adalah bentuk pembayaran (langsung atau tidak langsung) dalam bentuk mandat dan insentif untuk memotivasi karyawan agar produktifitas kerja semakin meningkat/ tinggi.Menurut Werther dan Davis dalam bukunya Wibowo (2010 : 348) kompensasi adalah apa yang diterima pekerja sebagai tukaran atas kontribusnya kepada organisasi.

Menurut Rivai (2010 : 744), kompensasi dapat dibedakan menjadi dua, yaitu: (1) kompensasi langsung adalah kompensasi yang langsung dirasakan oleh penerimanya, yakni berupa gaji, upah, insentif merupakan hak karyawan dan kewajiban perusahaan untuk membayarnya, dan (2) kompensasi tidak langsung adalah kompensasi yang tidak dapat dirasakan secara langsung oleh karyawan, yakni benefit dan services (tunjangan pelayanan).

Menurut Wibowo (2010 : 349) tujuan kompensasi adalah untuk membantu organisasi mencapai keberhasilan strategis sambil memastikan keadilan internal dan ekternal. Internal equity atau keadilan internal memastikan bahwa jabatan yang lebih menantang atau orang yang mempunyai kualifikasi lebih baik dalam organisasi dibayar lebih tinggi. Sementara itu, external equity atau keadilan eksternal menjamin bahwa pekerjaan mendapatkan kompensasi secara adil dalam perbandingan dengan pekerjaan yang sama di pasar tenaga kerjanya.

Pemberian kompensasi oleh organisasi dipengaruhi berbagai macam faktor. Faktorfaktor ini merupakan tantangan bagi setiap organisasi untuk menentukan kebijakan pemberian kompensasi. Menurut Sinambela (2016:235) berbagai faktor yang mempengaruhi kompensasi, yaitu:penawaran dan permintaan tenaga kerja, kemampuan dan kesediaan organisasi, serikat buruh, produktivitas kerja pegawai, pemerintah dengan undang-undang dan keppres, biaya hidup, posisi dan jabatan pegawai, pendidikan dan pengalaman kerja, dan kondisi perekonomian nasional, dan jenis dan sifat pekerjaan.

\section{Pengertian Kinerja}

Menurut Sinambela, dkk., (2016 : 480), mengemukakan bahwa kinerja pegawai didefenisikan sebagai kemampuan pegawai dalam melakukan sesuatu keahlian tertentu. Konerja pegawai sangatlah perlu, sebab dengan kinerja ini akan diketahui seberapa jauh kemampuan mereka dalam melaksanakan tugas yang dibebankan kepadanya. Menurut Rivai dan Basri dalam Sinambela (2016 : 482), kinerja adalah hasil atau tingkat keberhasilan seseorang atau keseluruhan selama periode tertentu dalam melaksanakan tugas dibandingkan dengan berbagai kemungkinan, seperti standar hasil kerja, target atau sasaran atau kriteria yang telah ditentukan terlebih dahulu dan telah disepakati bersama.

Robert L. Mathis dan John H. Jakson (2009 : 378) mendefinisikan kinerja (performance) adalah apa yang dilakukan atau tidak dilakukan oleh karyawan. Kinerja karyawan yang umum meliputi elemen yaitu : kuantitas dari hasil, kualitas dari hasil, ketepatan waktu dari hasil, kehadiran, dan kemampuan bekerja sama. Kinerja mempunyai makna lebih luas, bukan hanya menyatakan sebagai hasil kerja, tetapi bagaimana proses kerja berlangsung.

Bernardin dan Russell (2011 : 135) menyatakan kinerja (performance) adalah catatan outcome yang dihasilkan dari fungsi suatu pekerjaan tertentu selama periode waktu tertentu. Selanjutnya, Bernardin dan Russell (2011 : 157) menyatakan enam kriteria utama kinerja yang dapat dinilai antara lain :kualitas, kuantitas, ketepatan waktu, efektifitas biaya, kebutuhan pengawasan,dan pengaruh interpersonal.

\section{METODE PENELITIAN}

Penelitian ini dilakukan pada PT. Ira Widya Utama Medan yang beralamat di JL. Setiabudi, Blok J No.1, Komp.Taman Setiabudi Indah Medan. Ruang lingkup penelitian ini adalah komunikasi, budaya organsiasi, kompensasi dan kinerja karyawan Populasi_dalam 
penelitian ini adalah seluruh karyawan bagian produksi pada PT. Ira Widya Utama Medan tahun 2016 sebanyak 72 orang. Teknik penentuan sampel adalah metode sensus, artinya seluruh anggota populasi menjadi sampel penelitian.Teknik pengumpulan data yang digunakan adalahkuesioner dan dokumentasi. Teknik analisis data yang digunakan adalah analisis deskriptif dan analisis regresi linear berganda.

\section{HASIL PENELITIAN DAN PEMBAHASAN}

\section{a. Analisis Deskriptif}

Analisis deskriptif dilakukan untuk mengetahui berapa nilai frekuensi dan persentase yang diperoleh dari masing-masing alternatif jawaban yang diberikan oleh setiap responden dalam kuesioner penelitian. Deskripsi skor penilaian jawaban dari masing-masing variabel di dalam penelitian ini adalah sebagai berikut :

1. Deskripsi skor penilaian jawaban dari variabel komunikasi

Tabel 1. Jumlah dan Persentase Jawaban Responden Tentang Komunikasi

\begin{tabular}{|c|c|c|c|c|c|c|c|c|c|c|}
\hline \multirow{3}{*}{ Indikator penelitian } & \multicolumn{10}{|c|}{ Jumlah dan persentase jawaban responden } \\
\hline & \multicolumn{2}{|r|}{ SS } & \multicolumn{2}{|c|}{$\mathbf{S}$} & \multicolumn{2}{|c|}{ CS } & \multicolumn{2}{|c|}{ TS } & \multicolumn{2}{|c|}{ STS } \\
\hline & F & $\%$ & F & $\%$ & $\mathbf{F}$ & $\%$ & $\mathbf{F}$ & $\%$ & $\mathbf{F}$ & $\%$ \\
\hline Struktur & 28 & 38.9 & 28 & 38.9 & 11 & 15.3 & 5 & 6.9 & 0 & 0 \\
\hline Garis komando & 26 & 36.1 & 29 & 40.3 & 13 & 18.1 & 4 & 5.6 & 0 & 0 \\
\hline Komunikasi keluhan & 30 & 41.7 & 26 & 36.1 & 11 & 15.3 & 5 & 6.9 & 0 & 0 \\
\hline Sasaran lebih spesifik & 27 & 37.5 & 29 & 40.3 & 8 & 11.1 & 8 & 11.1 & 0 & 0 \\
\hline Dorongan & 28 & 38.9 & 22 & 30.6 & 10 & 13.9 & 12 & 16.7 & 0 & 0 \\
\hline Rangsangan bekerja & 26 & 36.1 & 30 & 41.7 & 10 & 13.9 & 6 & 8.3 & 0 & 0 \\
\hline Komunikasi efektif & 27 & 37.5 & 29 & 40.3 & 11 & 15.3 & 5 & 6.9 & 0 & 0 \\
\hline $\begin{array}{l}\text { Rasa pemenuhan } \\
\text { kebutuhan }\end{array}$ & 28 & 38.9 & 25 & 34.7 & 8 & 11.1 & 11 & 15.3 & 0 & 0 \\
\hline Sarana rasa emosi & 28 & 38.9 & 27 & 37.5 & 13 & 18.1 & 4 & 5.6 & 0 & 0 \\
\hline $\begin{array}{l}\text { Pengambilan } \\
\text { keputusan }\end{array}$ & 24 & 33.3 & 240 & $33.3 \mathrm{SH}$ & 15 & 20.8 & 9 & 12.5 & 0 & 0 \\
\hline $\begin{array}{l}\text { Informasi kepada } \\
\text { individu }\end{array}$ & 26 & 36.1 & 26 & 36.1 & 9 & 12.5 & 11 & 15.3 & 0 & 0 \\
\hline $\begin{array}{l}\text { Informasi kepada } \\
\text { kelompok }\end{array}$ & 27 & 37.5 & 27 & 37.5 & 13 & 18.1 & 5 & 6.9 & 0 & 0 \\
\hline Total & 325 & 451.4 & 322 & 447.2 & 132 & 183.3 & 85 & $\begin{array}{l}118 . \\
1\end{array}$ & & \\
\hline Rata-rata & & 37.6 & & 37.3 & & 15.3 & & 9.8 & & \\
\hline
\end{tabular}

Sumber: Data Diolah Dari Hasil Penelitian, 2017

Berdasarkan tabel 1 dapat diketahui bahwa responden yang memilih jawaban sangat setuju adalah sebanyak 37,6\%; responden yang memilih jawaban setuju adalah sebanyak $37,3 \%$; responden yang memilih jawaban cukup setuju adalah sebanyak 15,3\%; responden yang memilih jawaban tidak setuju adalah sebanyak 9,8\%.Dari keseluruhan jawaban responden terdapat $74,9 \%$ responden yang memilih jawaban sangat setuju dan jawaban setuju dimana persentase jawaban tersebut berada di antara skor penilaian antara 70 sampai dengan 79. Hal ini menunjukkan bahwa komunikasi dalam perusahaan ini dikategorikan baik, sedangkan dari keseluruhan jawaban responden terdapat 9,8\% responden yang memilih jawaban tidak setuju. 
Volume 18 Nomor 1

Tabel 2. Jumlah dan Persentase Jawaban Responden Tentang Budaya Organisasi

\begin{tabular}{|c|c|c|c|c|c|c|c|c|c|c|}
\hline \multirow{3}{*}{ Indikator penelitian } & \multicolumn{10}{|c|}{ Jumlah dan persentase jawaban responden } \\
\hline & \multicolumn{2}{|c|}{ SS } & \multicolumn{2}{|c|}{$\mathrm{S}$} & \multicolumn{2}{|c|}{ CS } & \multicolumn{2}{|c|}{ TS } & \multicolumn{2}{|c|}{ STS } \\
\hline & $\mathbf{F}$ & $\%$ & F & $\%$ & F & $\%$ & $\mathbf{F}$ & $\%$ & $\mathbf{F}$ & $\%$ \\
\hline $\begin{array}{l}\text { Interaksi dengan } \\
\text { bahasa }\end{array}$ & 24 & 33.3 & 24 & 33.3 & 16 & 22.2 & 8 & 11.1 & 0 & 0 \\
\hline Rasa hormat & 23 & 31.9 & 25 & 34.7 & 15 & 20.8 & 9 & 12.5 & 0 & 0 \\
\hline Tingkah laku & 25 & 34.7 & 29 & 40.3 & 11 & 15.3 & 7 & 9.7 & 0 & 0 \\
\hline Standar perilaku & 23 & 31.9 & 27 & 37.5 & 14 & 19.4 & 8 & 11.1 & 0 & 0 \\
\hline Panduan pekerjaan & 25 & 34.7 & 29 & 40.3 & 11 & 15.3 & 7 & 9.7 & 0 & 0 \\
\hline Jumlah pekerjaan & 26 & 36.1 & 26 & 36.1 & 14 & 19.4 & 6 & 8.3 & 0 & 0 \\
\hline $\begin{array}{l}\text { Nilai dalam } \\
\text { organisasi }\end{array}$ & 27 & 37.5 & 28 & 38.9 & 11 & 15.3 & 6 & 8.3 & 0 & 0 \\
\hline Produk berkualitas & 25 & 34.7 & 25 & 34.7 & 14 & 19.4 & 8 & 11.1 & 0 & 0 \\
\hline $\begin{array}{l}\text { Absesni yang } \\
\text { rendah }\end{array}$ & 24 & 33.3 & 27 & 37.5 & $14 \sqrt{2}$ & 19.4 & 7 & 9.7 & 0 & 0 \\
\hline Efisiensi yang tinggi & 21 & 29.2 & 27 & 37.5 & 15 & 20.8 & 9 & 12.5 & 0 & 0 \\
\hline Kebijakan & 26 & 36.1 & 26 & 36.1 & 9 & 12.5 & 11 & 15.3 & 0 & 0 \\
\hline Keyakinan & 27 & 37.5 & 27 & 37.5 & 13 & 18.1 & 5 & 6.9 & 0 & 0 \\
\hline $\begin{array}{l}\text { Pergaulan dalam } \\
\text { organisasi }\end{array}$ & 26 & 36.1 & 26 & 36.1 & 11 & 15.3 & 9 & 12.5 & 0 & 0 \\
\hline Belajar & 24 & 33.3 & 26 & 36.1 & 13 & 18.1 & 9 & 12.5 & 0 & 0 \\
\hline Beradaptasi & 26 & 36.1 & 25 & 34.7 & 13 & 18.1 & 8 & 11.1 & 0 & 0 \\
\hline Perasaan & 24 & 33.3 & 25 & 34.7 & 12 & 16.7 & 11 & 15.3 & 0 & 0 \\
\hline Tata ruang & 28 & 38.9 & 27 & 37.5 & 13 & 18.1 & 4 & 5.6 & 0 & 0 \\
\hline Interaksi & 23 & 31.9 & 24 & 33.3 & 16 & 22.2 & 9 & 12.5 & 0 & 0 \\
\hline Perilaku & 25 & 34.7 & 26 & 36.1 & 9 & 12.5 & 12 & 16.7 & 0 & 0 \\
\hline Total & 472 & 655.6 & 499 & 693.1 & 244 & 338.9 & 153 & 212.5 & & \\
\hline Rata-rata & & 34.5 & DAT & 36.5 & SN & 17.8 & & 11.2 & & \\
\hline
\end{tabular}

Sumber: Data Diolah Dari Hasil Penelitian, 2017

Berdasarkan tabel 2 dapat diketahui bahwa responden yang memilih jawaban sangat setuju adalah sebanyak 34,5\%; responden yang memilih jawaban setuju adalah sebanyak $36,5 \%$; responden yang memilih jawaban cukup setuju adalah sebanyak 15,3\%; responden yang memilih jawaban tidak setuju adalah sebanyak 11,2\%.Dari keseluruhan jawaban responden terdapat $71,0 \%$ responden yang memilih jawaban sangat setuju dan jawaban setuju dimana persentase jawaban tersebut berada di antara skor penilaian antara 70 sampai dengan 79. Hal ini menunjukkan bahwa komunikasi dalam perusahaan ini dikategorikan baik, sedangkan dari keseluruhan jawaban responden terdapat $11,2 \%$ responden yang memilih jawaban tidak setuju.

c. Deskripsi skor penilaian jawaban dari variabel kompensasi

Tabel 3. Jumlah dan Persentase Jawaban Responden Tentang Kompensasi

\begin{tabular}{|c|c|c|c|c|c|c|c|c|c|c|}
\hline \multirow{3}{*}{ Indikator penelitian } & \multicolumn{10}{|c|}{ Jumlah dan persentase jawaban responden } \\
\hline & \multicolumn{2}{|c|}{ SS } & \multicolumn{2}{|l|}{$\mathbf{S}$} & \multicolumn{2}{|c|}{ CS } & \multicolumn{2}{|c|}{ TS } & \multicolumn{2}{|c|}{ STS } \\
\hline & $\mathbf{F}$ & $\%$ & $\mathbf{F}$ & $\%$ & $\mathbf{F}$ & $\%$ & $\mathbf{F}$ & $\%$ & $\mathbf{F}$ & $\%$ \\
\hline $\begin{array}{l}\text { Permintaan tenaga } \\
\text { kerja }\end{array}$ & 24 & 33.3 & 23 & 31.9 & 18 & 25.0 & 7 & 9.7 & 0 & 0 \\
\hline
\end{tabular}


Volume 18 Nomor 1

\begin{tabular}{|c|c|c|c|c|c|c|c|c|c|c|}
\hline $\begin{array}{l}\text { Penawaran tenaga } \\
\text { kerja }\end{array}$ & 23 & 31.9 & 35 & 48.6 & 9 & 12.5 & 5 & 6.9 & 0 & 0 \\
\hline $\begin{array}{l}\text { Kemampuan } \\
\text { organisasi }\end{array}$ & 25 & 34.7 & 24 & 33.3 & 11 & 15.3 & 12 & 16.7 & 0 & 0 \\
\hline Kesediaan organisasi & 24 & 33.3 & 25 & 34.7 & 15 & 20.8 & 8 & 11.1 & 0 & 0 \\
\hline Serikat buruh & 21 & 29.2 & 22 & 30.6 & 19 & 26.4 & 10 & 13.9 & 0 & 0 \\
\hline Peraturan pemerintah & 22 & 30.6 & 25 & 34.7 & 16 & 22.2 & 9 & 12.5 & 0 & 0 \\
\hline Keputusan Presiden & 24 & 33.3 & 26 & 36.1 & 13 & 18.1 & 9 & 12.5 & 0 & 0 \\
\hline Biaya hidup tinggi & 24 & 33.3 & 25 & 34.7 & 13 & 18.1 & 10 & 13.9 & 0 & 0 \\
\hline Biaya hidup rendah & 25 & 34.7 & 26 & 36.1 & 12 & 16.7 & 9 & 12.5 & 0 & 0 \\
\hline Posisi pegawai & 24 & 33.3 & 24 & 33.3 & 15 & 20.8 & 9 & 12.5 & 0 & 0 \\
\hline Jabatan tinggi & 26 & 36.1 & 23 & 31.9 & 12 & 16.7 & 11 & 15.3 & 0 & 0 \\
\hline Pendidikan & 23 & 31.9 & $21 D$ & 29.2 & 16 & 22.2 & 12 & 16.7 & 0 & 0 \\
\hline Ketrampilan & 23 & 31.9 & 27 & 37.5 & 11 & 15.3 & 12 & 16.7 & 0 & 0 \\
\hline $\begin{array}{l}\text { Kondisi } \\
\text { perekonomian baik }\end{array}$ & 5 & 34.7 & 28 & 38.9 & 11 & 15.3 & 8 & 11.1 & 0 & 0 \\
\hline $\begin{array}{l}\text { Kondisi } \\
\text { perekonomian kurang }\end{array}$ & 25 & 34.7 & 28 & 38.9 & 11 & 15.3 & 8 & 11.1 & 0 & 0 \\
\hline Sifat pekerjaan & 21 & 29.2 & 27 & 37.5 & 13 & 18.1 & 11 & 15.3 & 0 & 0 \\
\hline $\begin{array}{l}\text { Pekerjaan yang } \\
\text { beresiko }\end{array}$ & 22 & 30.6 & 23 & 31.9 & 14 & 19.4 & 13 & 18.1 & 0 & 0 \\
\hline Total & 401 & $\begin{array}{l}556 . \\
9\end{array}$ & 432 & $\begin{array}{l}600 . \\
0\end{array}$ & 229 & $\begin{array}{l}318 . \\
1\end{array}$ & 163 & $\begin{array}{l}226 . \\
4\end{array}$ & 0 & 0 \\
\hline Rata-rata & & 32.8 & & 35.3 & & 18.7 & & 13.3 & 0 & 0 \\
\hline
\end{tabular}

Sumber: Data Diolah Dari Hasil Penelitian, 2017

Berdasarkan tabel 3 dapat diketahui bahwa responden yang memilih jawaban sangat setuju adalah sebanyak 32,8\%; responden yang memilih jawaban setuju adalah sebanyak $35,3 \%$; responden yang memilih jawaban cukup setuju adalah sebanyak 18,7\%; responden yang memilih jawaban tidak setuju adalah sebanyak 13,3\%. Dari keseluruhan jawaban responden terdapat $68,1 \%$ responden yang memilih jawaban sangat setuju dan jawaban setuju dimana persentase jawaban tersebut berada di antara skor penilaian antara 60 sampai dengan 69. Hal ini menunjukkan bahwa komunikasi dalam perusahaan ini dikategorikan cukup baik, sedangkan dari keseluruhan jawaban responden terdapat $13,3 \%$ responden yang memilih jawaban tidak setuju.

\section{d. Deskripsi skor penilaian jawaban dari variabel Kinerja}

Tabel 4. Jumlah dan Persentase Jawaban Responden Tentang Kinerja

\begin{tabular}{|c|c|c|c|c|c|c|c|c|c|c|}
\hline \multirow{3}{*}{ Indikator penelitian } & \multicolumn{10}{|c|}{ Jumlah dan persentase jawaban responden } \\
\hline & \multicolumn{2}{|c|}{ SS } & \multicolumn{2}{|c|}{$\mathrm{S}$} & \multicolumn{2}{|c|}{ CS } & \multicolumn{2}{|c|}{ TS } & \multicolumn{2}{|c|}{ STS } \\
\hline & $\mathbf{F}$ & $\%$ & $\mathbf{F}$ & $\%$ & $\mathbf{F}$ & $\%$ & $\mathbf{F}$ & $\%$ & $\mathbf{F}$ & $\%$ \\
\hline $\begin{array}{l}\text { Karyawan selalu } \\
\text { memperhatikan } \\
\text { pekerjaan }\end{array}$ & 22 & 30.6 & 23 & 31.9 & 15 & 20.8 & 12 & 16.7 & 0 & 0 \\
\hline $\begin{array}{l}\text { Karyawan selalu } \\
\text { berusaha bekerja dengan } \\
\text { baik }\end{array}$ & 25 & 34.7 & 25 & 34.7 & 13 & 18.1 & 9 & 12.5 & 0 & 0 \\
\hline
\end{tabular}

Analisis Pengaruh Komunikasi, Budaya Organisasi dan Kompensasi Terhadap Kinerja Karyawan 35 pada PT. Ira Widya Utama Medan. Oleh : Sahat Simbolon 


\begin{tabular}{|c|c|c|c|c|c|c|c|c|c|c|}
\hline \multirow{3}{*}{ Indikator penelitian } & \multicolumn{10}{|c|}{ Jumlah dan persentase jawaban responden } \\
\hline & \multicolumn{2}{|c|}{ SS } & \multicolumn{2}{|c|}{$\mathrm{S}$} & \multicolumn{2}{|c|}{$\mathrm{CS}$} & \multicolumn{2}{|c|}{ TS } & \multicolumn{2}{|c|}{ STS } \\
\hline & $\mathbf{F}$ & $\%$ & $\mathbf{F}$ & $\%$ & $\mathbf{F}$ & $\%$ & $\mathbf{F}$ & $\%$ & $\mathbf{F}$ & $\%$ \\
\hline $\begin{array}{l}\text { Besaran yang dihasilkan } \\
\text { karyawan dalam bentuk } \\
\text { uang }\end{array}$ & 21 & 29.2 & 24 & 33.3 & 17 & 23.6 & 10 & 13.9 & 0 & 0 \\
\hline $\begin{array}{l}\text { Karyawan berusaha } \\
\text { mencapai target }\end{array}$ & 24 & 33.3 & 25 & 34.7 & 15 & 20.8 & 8 & 11.1 & 0 & 0 \\
\hline $\begin{array}{l}\text { Karyawan berusaha } \\
\text { hadir tepat waktu }\end{array}$ & 23 & 31.9 & 23 & 31.9 & 17 & 23.6 & 9 & 12.5 & 0 & 0 \\
\hline $\begin{array}{l}\text { Karyawan berusaha } \\
\text { menyelesaikan tugas } \\
\text { dengan tepat waktu }\end{array}$ & 26 & 36.1 & 24 & 33.3 & 10 & 13.9 & 12 & 16.7 & 0 & 0 \\
\hline $\begin{array}{l}\text { Penggunaan sumber- } \\
\text { sumber daya } \\
\text { dimaksimalkan }\end{array}$ & 25 & $34.7 \mathrm{~S}$ & $25 D$ & 34.7 & 13 & 18.1 & 9 & 12.5 & 0 & 0 \\
\hline $\begin{array}{l}\text { Karyawan berusaha } \\
\text { mencapai target yang } \\
\text { tinggi }\end{array}$ & 22 & 30.6 & 25 & 34.7 & 17 & 23.6 & 8 & 11.1 & 0 & 0 \\
\hline $\begin{array}{l}\text { Karyawan perlu } \\
\text { pengawasan dalam } \\
\text { menyelesaikan tugas }\end{array}$ & 25 & 34.7 & 23 & 31.9 & 13 & 18.1 & 11 & 15.3 & 0 & 0 \\
\hline $\begin{array}{l}\text { Pengawasan yang } \\
\text { rendah akan mendapat } \\
\text { hasil rendah }\end{array}$ & 24 & 33.3 & 24 & 33.3 & 15 & $\frac{20.8}{\frac{\pi}{4}}$ & 9 & 12.5 & 0 & 0 \\
\hline $\begin{array}{l}\text { Karyawan menunjukkan } \\
\text { harga diri }\end{array}$ & 25 & 34.7 & 26 & 36.1 & 11 & 15.3 & 10 & 13.9 & 0 & 0 \\
\hline $\begin{array}{l}\text { Kerjasama antar } \\
\text { karyawan sangat } \\
\text { penting }\end{array}$ & 24 & 33.3 & 25 & $\begin{array}{l}34.7 \\
\mathrm{~K}\end{array}$ & 14 & 19.4 & 9 & 12.5 & 0 & 0 \\
\hline Total & 286 & $\begin{array}{l}397 . \\
2\end{array}$ & 292 & $\begin{array}{l}405 . \\
6\end{array}$ & 170 & $\begin{array}{l}236 . \\
1\end{array}$ & 116 & $\begin{array}{l}161 . \\
1\end{array}$ & & \\
\hline Rata-rata & & 33.1 & & 33.8 & & 19.7 & & 13.4 & & \\
\hline
\end{tabular}

Sumber: Data Diolah Dari Hasil Penelitian, 2017

Berdasarkan tabel 4 dapat diketahui bahwa responden yang memilih jawaban sangat setuju adalah sebanyak 33,1\%; responden yang memilih jawaban setuju adalah sebanyak $33,8 \%$; responden yang memilih jawaban cukup setuju adalah sebanyak 19,7\%; responden yang memilih jawaban tidak setuju adalah sebanyak 13,4\%.Dari keseluruhan jawaban responden terdapat $66,9 \%$ responden yang memilih jawaban sangat setuju dan jawaban setuju dimana persentase jawaban tersebut berada di antara skor penilaian antara 60 sampai dengan 69. Hal ini menunjukkan bahwa komunikasi dalam perusahaan ini dikategorikan cukup baik, sedangkan dari keseluruhan jawaban responden terdapat $13,4 \%$ responden yang memilih jawaban tidak setuju.

\section{e. Uji Multikolinearitas}

Hasil uji multikolinearitas untuk pengaruh di antara variabel komunikasi, budaya organisasi dan variabel kompensasi terhadap variabel kinerja karyawan adalah sebagai berikut : 
Volume 18 Nomor 1

Tabel 5. Hasil Uji Multikolinearitas Untuk Pengaruh di antara Komunikasi, Variabel Budaya Coefficients $^{\mathrm{a}}$

Organisasi dan Variabel Kompensasi terhadap Variabel Kinerja Karyawan

\begin{tabular}{|l|l|l|l|l|l|l|l|}
\hline \multirow{3}{*}{ Model } & \multicolumn{2}{|l|}{$\begin{array}{l}\text { Unstandardized } \\
\text { Coefficien }\end{array}$} & $\begin{array}{l}\text { Standardized } \\
\text { Coefficients }\end{array}$ & \multirow{2}{*}{$\mathbf{t}$} & \multirow{2}{*}{ Sig } & \multicolumn{2}{l|}{$\begin{array}{l}\text { Collinearity } \\
\text { Statistics }\end{array}$} \\
\cline { 2 - 8 } & B & $\begin{array}{l}\text { Std. } \\
\text { Error }\end{array}$ & Beta & & & $\begin{array}{l}\text { Toleranc } \\
\text { e }\end{array}$ & VIF \\
\hline 1 Constant) & 11,334 & 6,117 & &, 877 &, 004 & & \\
Komunikasi &, 457 &, 523 &, 296 & 5,324 &, 001 &, 425 & 3,652 \\
Budaya Organisasi &, 387 &, 452 &, 288 & 3,962 &, 003 &, 433 & 3,652 \\
Kompensasi &, 553 &, 619 &, 390 & 6,783 &, 001 &, 379 & 3,652 \\
\hline
\end{tabular}

Dependent Variable: Kinerja Karyawan

Sumber : Data Diolah Dari Hasil Penelitian, 2017

Berdasarkan tabel 5 dapat diketahui bahwa nilai tolerance dari hasil uji multikolinearitas untuk variabel komunikasi $\left(X_{1}\right)$ sebesar 0,425 , variabel budaya organisasi $\left(X_{2}\right)$ sebesar 0,433 dan variabel kompensasi $\left(X_{3}\right)$ adalah 0,379. Nilai VIF dari hasil uji multikolinearitas untuk variabel komunikasi $\left(X_{1}\right)$, variabel budaya organisasi $\left(X_{2}\right)$ dan variabel kompensasi $\left(X_{3}\right)$ adalah 3,652 dimana nilai tolerance yang dihasilkan adalah $>0,10$ dan nilai VIF yang dihasilkan adalah < 10, maka dapat disimpulkan bahwa tidak terjadi multikolinearitas atau tidak ditemukan adanya korelasi di antara variabel bebas yaitu komunikasi, budaya organisasi dan kompensasi dalam model regresi di dalam penelitian ini.

\section{f. Uji Normalitas}

Hasil uji normalitas untuk variabel komunikasi, variabel budaya organisasi, variabel kompensasi, dan variabel kinerja karyawan adalah sebagai berikut:

Tabel 6. Hasil Uji Normalitas Untuk variabel Komunikasi, Variabel Budaya Organisasi, Variabel Kompensasi dan Variabel Kinerja Karyawan One-Sample Kolmogorov-Smirnov Test

\begin{tabular}{|l|l|l|l|l|}
\hline & $\begin{array}{c}\text { Komunik } \\
\text { asi }\end{array}$ & \multicolumn{1}{|c|}{$\begin{array}{c}\text { Budaya } \\
\text { Organisasi }\end{array}$} & \multicolumn{1}{c|}{ Kompensasi } & \multicolumn{1}{|c|}{$\begin{array}{c}\text { Kinerja } \\
\text { Karyawan }\end{array}$} \\
\hline N & 72 & 2 & 72 & 72 \\
Normal Parametersa,b & 22,4562 & 20,5611 & 18,3341 & 24,9762 \\
& 5,1262 & 4,5990 & 3,2242 & 5,0034 \\
Most Extreme & 287 & 217 & 202 & 296 \\
Differences & 085 & 099 & 104 & 132 \\
& -287 & -217 &,- 202 &,- 296 \\
Test Statistic & 287 &, 217 & 202 & 296 \\
Asymp. Sig. (2-tailed) & 202 c & 193 c & $166^{c}$ &, $254^{c}$ \\
\hline
\end{tabular}

a. Test distribution is Normal.

b. Calculated from data.

c. Lilliefors Significance Correction.

Sumber : Data Diolah Dari Hasil Penelitian, 2017

Berdasarkan tabel 6 dapat diketahui bahwa nilai $p$ value Sig atau nilai signifikansi dari variabel komunikasi adalah 0,202, variabel budaya organisasi adalah 0,193; nilai p value Sig atau nilai signifikansi dari variabel kompensasi adalah 0,166 ; dan nilai $\mathrm{p}$ value Sig atau nilai signifikansi dari variabel kinerja karyawan adalah 0,254 dimana semua nilai $p$ value Sig atau 
nilai signifikansi yang dihasilkan adalah $>0,05$, maka dapat disimpulkan bahwa data yang diuji di dalam penelitian ini adalah berdistribusi normal.

\section{g. Analisis Regresi Linear Berganda}

Hasil analisis regresi linear berganda untuk pengaruh di antara variabel komunikasi, variabel budaya organisasi dan variabel kompensasi terhadap variabel kinerja karyawan adalah sebagai berikut :

Tabel 7.Hasil Analisis Regresi Linear Berganda Untuk Pengaruh di antara variabel

Komunikasi, Variabel Budaya Organisasi dan Variabel Kompensasi terhadap Variabel Kinerja Karyawan

Coefficients ${ }^{\mathrm{a}}$

\begin{tabular}{|c|c|c|c|c|c|}
\hline \multirow[t]{2}{*}{ Model } & \multicolumn{2}{|c|}{$\begin{array}{l}\text { Unstandardized } \\
\text { Coefficien }\end{array}$} & $\begin{array}{l}\text { Standardized } \\
\text { Coefficients }\end{array}$ & \multirow[t]{2}{*}{$\mathbf{t}$} & \multirow[t]{2}{*}{ Sig } \\
\hline & B & Std. Error & Beta & & \\
\hline 1 (Constant) & 11,334 & 12,923 & सU & 877 & ,004 \\
\hline $\begin{array}{l}\text { Komunikasi } \\
\text { Budava }\end{array}$ & 457 & ,086 & & 5,324 & ,001 \\
\hline $\begin{array}{l}\text { Organisasi } \\
\text { Kompensasi }\end{array}$ & $\begin{array}{l}, 387 \\
, 553\end{array}$ & $\begin{array}{l}, 097 \\
082\end{array}$ & $\begin{array}{l}288 \\
390\end{array}$ & $\begin{array}{l}3,962 \\
6,783\end{array}$ & $\begin{array}{l}003 \\
001\end{array}$ \\
\hline
\end{tabular}

a. Dependent Variable: Kinerja Karyawan

Sumber : Data Diolah Dari Hasil Penelitian, 2017

Berdasarkan tabel 7 dapat diketahui bahwa koefisien a adalah 11,334; koefisien $b_{1}$ adalah 0,457; koefisien $b_{2}$ adalah 0,387 dan koefisien $b_{3}$ adalah 0,553. Koefisien a merupakan besarnya harga variabel $Y$ apabila harga variabel $X_{1}$, harga variabel $X_{2}$ dan harga variabel $X_{3}=$ 0 , sedangkan koefisien $b$ adalah nilai koefisien regresi variabel $Y$ atas variabel $X_{1}, X_{2}$ dan variabel $X_{2}$. Berdasarkan hasil dari perhitungan analisis regresi linear berganda, maka diperoleh persamaan sebagai berikut :

Tabel 8.Persamaan Analisis Regresi Linear Berganda untuk Pengaruh di antara Variabel

Budaya Organisasi dan Variabel Kompensasi terhadap Variabel Kinerja Karyawan

\begin{tabular}{|l|l|l|}
\hline & & Persamaan Analisis Regresi Linear Berganda \\
\cline { 1 - 2 } & 11,334 & \multirow{3}{*}{$\mathrm{Y}=11,334+0,457 . \mathrm{X}_{1}+0,387 \cdot \mathrm{X}_{2}+0,553 . \mathrm{X}_{2}$} \\
\cline { 1 - 2 } $\mathrm{b}_{1}$ & 0,457 & \\
\cline { 1 - 2 } $\mathrm{b}_{2}$ & 0,387 & \\
\hline $\mathrm{B}_{3}$ & 0,553 & \\
\cline { 1 - 2 } & &
\end{tabular}

Sumber : Data Diolah Dari Hasil Penelitian, 2017

Berdasarkan tabel 8 dapat diketahui bahwa nilai komponen a atau konstanta sebesar 11,334 merupakan nilai $Y$ apabila nilai $X_{1}, X_{2}$ dan nilai $X_{3}=0$; nilai komponen $b_{1}$ atau koefisien regresi untuk variabel komunikasi sebesar 0,457 menandakan bahwa variabel komunikasi mempunyai hubungan yang searah dengan variabel kinerja karyawan yang artinya semakin baik komunikasi yang diterapkan oleh pimpinan perusahaan terhadap bawahan, maka kinerja yang dihasilkan oleh karyawan akan semakin meningkat, sebaliknya semakin kurang baik komunikasi yang diterapkan oleh pimpinan perusahaan, maka kinerja yang dihasilkan oleh karyawan akan semakin menurun.

Nilai komponen $b_{2}$ atau koefisien regresi untuk variabel budaya organisasi sebesar 0,387 menandakan bahwa variabel budaya organisasi mempunyai hubungan yang searah dengan variabel kinerja karyawan yang artinya semakin kuat budaya organisasi yang diterapkan oleh pimpinan perusahaan, maka kinerja yang dihasilkan oleh karyawan akan semakin meningkat, sebaliknya semakin lemah budaya organisasi yang diterapkan oleh Analisis Pengaruh Komunikasi, Budaya Organisasi dan Kompensasi Terhadap Kinerja Karyawan 38 pada PT. Ira Widya Utama Medan. Oleh : Sahat Simbolon 
pimpinan perusahaan, maka kinerja yang dihasilkan oleh karyawan akan semakin menurun. Nilai komponen $b_{3}$ atau koefisien regresi untuk variabel kompensasi sebesar 0,553 menandakan bahwa variabel kompensasi mempunyai hubungan yang searah dengan variabel kinerja karyawan yang artinya semakin tinggi kompensasi yang dirasakan oleh karyawan, maka karyawan akan menunjukkan kinerja semakin meningkat, sebaliknya semakin rendah kompensasi yang dirasakan oleh karyawan, maka kinerja karyawan semakin menurun.

Berdasarkan hasil perhitungan uji signifikansi di dalam analisis regresi linear berganda diketahui bahwa nilai $\mathrm{p}$ value Sig atau nilai signifikansi dari pengaruh di antara variabel komunikasi terhadap variabel kinerja karyawan adalah 0,001 dimana nilai $p$ value Sig atau nilai signifikansi yang dihasilkan adalah $<0,05$, maka dapat disimpulkan bahwa regresi pengaruh di antara variabel komunikasiterhadap variabel kinerja karyawan di dalam penelitian ini adalah signifikan. Nilai $\mathrm{p}$ value sig atau nilai signifikansi dari pengaruh di antara variabel budaya organisasi terhadap variabel kinerja karyawan adalah 0,003 dimana nilai $\mathrm{p}$ value sig atau nilai signifikansi yang dihasilkan adalah $<0,05$, maka dapat disimpulkan bahwa regresi pengaruh di antara variabel budaya organisasi terhadap variabel kinerja karyawan di dalam penelitian ini adalah signifikan. Nilai $p$ value sig atau nilai signifikansi dari pengaruh di antara variabel kompensasi terhadap variabel kinerja karyawan adalah 0,001 dimana nilai $\mathrm{p}$ value sig atau nilai signifikansi yang dihasilkan adalah $<0,05$, maka dapat disimpulkan bahwa regresi pengaruh di antara variabel kompensasi terhadap variabel kinerja karyawan di dalam penelitian ini adalah signifikan.

\section{h. Uji Koefisien Korelasi Linear Berganda}

Hasil uji koefisien korelasi linear berganda untuk pengaruh di antara variabel komunikasi, variabel budaya organisasi dan variabel kompensasi terhadap variabel kinerja karyawan adalah sebagai berikut :

Tabel 9.Hasil Uji Koefisien Korelasi Linear Berganda untuk Pengaruh di antara Variabel Komunikasi, Variabel Budaya Organisasi dan Variabel Kompensasi terhadap Variabel Kinerja Karyawan

Model Summary

\begin{tabular}{|l|r|r|r|r|}
\hline Model & \multicolumn{1}{|c|}{ R } & R Square & Adjusted R Square & Std. Error of the Estimate \\
\hline 1 &, $901^{\mathrm{a}}$ &, 812 &, 8.04 & 4,3341 \\
\hline
\end{tabular}

a. Predictors: (Constant), Komunikasi, Budaya Organisasi, Kompensasi

Sumber : Data Diolah Dari Hasil Penelitian, 2017

Tabel 10. Hasil Acuan Interpretasi Uji Koefisien Korelasi Linear Berganda Untuk Pengaruh Antara Variabel Komunikasi, Variabel Budaya Organisasi dan Variabel Kompensasi terhadap Variabel Kinerja Karyawan

\begin{tabular}{|c|c|c|c|c|}
\hline \multirow{2}{*}{ a) Hubungan Variabel } & \multicolumn{5}{|c|}{ b) Korelasi } \\
\cline { 2 - 6 } & c) $\mathbf{r}_{\text {hitung }}$ & d) Interval Koefisien & e) Tingkat Hubungan \\
\hline f) $\operatorname{Ryx}_{1} x_{2}$ & g) 0,901 & h) $0,800-1,000$ & i) Sangat Kuat \\
\hline
\end{tabular}

Sumber : Data Diolah Dari Hasil Penelitian, 2017

Berdasarkan tabel 10 dapat diketahui bahwa hasil uji koefisien korelasi linear berganda untuk pengaruh antara variabel komunikasi, variabel budaya organisasi dan variabel kompensasi terhadap variabel kinerja karyawan adalah 0,901 yang berada pada interval koefisien antara 0,800 - 1,000 dengan tingkat hubungan yang sangat kuat. Hal ini berarti komunikasi, budaya organisasi dan kompensasi mempunyai pengaruh yang sangat kuat terhadap kinerja karyawan pada PT. Ira Widya Utama Medan. 


\section{i. Uji Hipotesis Secara Parsial atau Uji t}

Hasil uji hipotesis parsial atau uji t untuk pengaruh di antara variabel komunikasi, budaya organisasi dan kompensasi secara individual dalam menerangkan kinerja karyawan adalah sebagai berikut :

Tabel 11.Hasil Uji Hipotesis Parsial Atau Uji T Untuk Pengaruh Antara Variabel Komunikasi, Budaya Organisasi dan Kompensasi Dalam Menerangkan Variabel Kinerja

Coefficients $^{\mathrm{a}}$

Karyawan

\begin{tabular}{|c|c|c|c|c|c|}
\hline \multirow[t]{2}{*}{ Model } & \multicolumn{2}{|c|}{$\begin{array}{l}\text { Unstandardized } \\
\text { Coefficien }\end{array}$} & $\begin{array}{l}\text { Standardized } \\
\text { Coefficients }\end{array}$ & \multirow[t]{2}{*}{$\mathbf{t}$} & \multirow[t]{2}{*}{ Sig } \\
\hline & B & Std. Error & Beta & & \\
\hline $1 \quad$ (Constant) & 11,334 & 12,923 & & 877 & ,004 \\
\hline Komunikasi & ,457 & ,086 & 296, & 5,324 & ,001 \\
\hline Budaya Organisasi & & & & & \\
\hline Kompensasi & $\begin{array}{l}387 \\
, 553\end{array}$ & $\begin{array}{l}, 097 D I] \\
, 082\end{array}$ & 288 & $\begin{array}{l}3,962 \\
6,783\end{array}$ & $\begin{array}{l}, 003 \\
, 001\end{array}$ \\
\hline
\end{tabular}

a. Dependent Variable: Kinerja Karyawan

Sumber : Data Diolah Dari Hasil Penelitian, 2017

Berdasarkan tabel 11 hasil uji hipotesis secara parsial atau uji tuntuk variabel komunikasi $t$ hitung adalah 5,324 hal inimenunjukkan bahwa hal ini berarti $t_{\text {hitung }}>t_{\text {tabel }}$ $(5,324>1,670)$ artinyakomunikasimempunyai pengaruh yang positif dan signifikan terhadap kinerja karyawan pada PT. Ira Widya Utama Medan.Untuk variabel budaya organisasi, $t$ hitung sebesar3,962, sedangkan $t_{\text {tabel }} 1,670$, hal ini berarti $t_{\text {hitung }}>t_{\text {tabel }}(3,962>1,670)$ artinya budaya organisasi mempunyai pengaruh yang positif dan signifikan terhadap kinerja karyawan pada PT. Ira Widya Utama Medan. Untuk variabel kompensasi $t$ hitung adalah 6,783 , hal ini berarti $t_{\text {hitung }}>t_{\text {tabel }}(6,783>1,670)$ artinya kompensasi mempunyai pengaruh yang positif dan signifikan terhadap kinerja karyawan pada PT. Ira Widya Utama Medan.

\section{j. Uji Hipotesis Simultan atau Uji F}

Hasil uji hipotesis secara simultan atau uji $\mathrm{F}$ untuk pengaruh di antara variabel komunikasi, variabel budaya organisasidan variabel kompensasisecara bersama-sama terhadap variabel kinerja karyawan adalah sebagai berikut :

Tabel 12. Hasil Uji Hipotesis Simultan Atau Uji F Untuk Pengaruh Antara Variabel Komunikasi, Variabel Budaya Organisasi Dan Variabel Kompensasi Secara

Bersama-Sama Terhadap Variabel Kinerja Karyawan

\begin{tabular}{|ll|r|r|r|r|r|}
\hline Model & & \multicolumn{1}{|c|}{$\begin{array}{c}\text { Sum of } \\
\text { Squares }\end{array}$} & \multicolumn{1}{c|}{ df } & Mean Square & \multicolumn{1}{c|}{ F } & Sig. \\
\hline 1 & Regression & 599,021 & 3 & 203,774 & 100,561 &, $000^{\mathrm{b}}$ \\
& Residual & 234.061 & 68 & 20,566 & & \\
& Total & 833.082 & 71 & & & \\
\hline
\end{tabular}

a. Dependent Variable: Kinerja Karyawan

b. Predictors: (Constant), Komunikasi, Budaya Organisasi, Kompensasi

Sumber : Data Diolah Dari Hasil Penelitian, 2017

Berdasarkan tabel 12dapat diketahui bahwa $F_{\text {hitung yang dihasilkan dari uji hipotesis }}$ secara simultan atau uji $\mathrm{F}$ untuk pengaruh variabel komunikasi, budaya organisasi dan kompensasi secara bersama-sama terhadap kinerja karyawan adalah 100,561, sedangkan

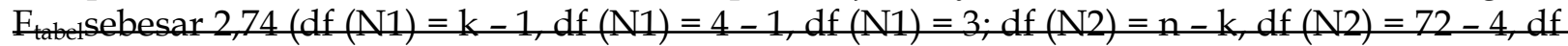
Analisis Pengaruh Komunikasi, Budaya Organisasi dan Kompensasi Terhadap Kinerja Karyawan 40 pada PT. Ira Widya Utama Medan. Oleh : Sahat Simbolon 
$(\mathrm{N} 2)=68$ dengan taraf kesalahan 5\%), hal ini berarti $F_{\text {hitung }}>F_{\text {tabel }}(100,561>2,74)$ yang artinya bahwa variabel komunikasi, budaya organisasi dan kompensasi mempunyai pengaruh yang positif dan signifikan terhadap kinerja karyawan pada PT. Ira Widya Utama Medan.

\section{k. Perhitungan Koefisien Determinasi}

Hasil perhitungan koefisien determinasi untuk kontribusi di antara variabel komunikasi,budaya organisasi dan kompensasiterhadap kinerja karyawan adalah sebagai berikut :

Tabel 13.Hasil Perhitungan Koefisien Determinasi Untuk Kontribusi Antara Variabel Komunikasi, Variabel Budaya Organisasidan Variabel Kompensasi terhadap Variabel Kinerja Karyawan

Model Summary

\begin{tabular}{|l|c|r|r|r|}
\hline Model & R & R Square & Adjusted R Square & Std. Error of the Estimate \\
\hline 1 &, $901^{\mathrm{a}}$ &, 812 &, 8.04 & 4,3341 \\
\hline
\end{tabular}

a. Predictors: (Constant),Komunikasi, Budaya Organisasi, Kompensasi

Sumber : Data Diolah Dari Hasil Penelitian, 2017

Berdasarkan tabel 13 dapat diketahui bahwa hasil perhitungan koefisien determinasi untuk kontribusi di antara variabel komunikasi,budaya organisasi dan kompensasi terhadap kinerja karyawan adalah 0,812 atau 81,2\%. Hal ini menunjukkan bahwa kontribusi dari variabel komunikasi, budaya organisasidan kompensasi untuk meningkatkan variabel kinerja karyawan adalah sebesar 0,812 atau $81,2 \%$, sedangkan sisa 0,188 atau 18,8\% dipengaruhi oleh variabel lain yang tidak diteliti di dalam penelitian ini, seperti motivasi kerja, kepemimpinan, lingkungan kerja, kompetensi, komitmen kerja dan lain sebagainya.

\section{B. Pembahasan}

\section{a. Pengaruh Komunikasi Terhadap Kinerja Karyawan}

Menurut Frances G. Chandle dalam bukunya Manullang (2014 :253) komunikasi adalah proses pertukaran pikiran, perasaan dan informasi. Sementara Luthans (2011:70), komunikasi adalah proses yang diperlukan oleh manajemen melakukan fungsinya, perencanaan, organizing, leading, dan controlling dapat tercapainya melalui proses komunikasi memungkinkan manajer menemban tanggung jawab yang dilimpahkan perusahaan padanya.Hal ini didukung keseluruhan jawaban responden untuk pernyataan dari variabel budaya organisasi terdapat $74,9 \%$ responden yang memilih jawaban sangat setuju dan jawaban setuju. Hal ini menunjukkan bahwa komunikasi dalam perusahaan ini dikategorikan baik, sedangkan dari keseluruhan jawaban responden terdapat 9,8\% responden yang memilih jawaban tidak setuju. Berdasarkan hasil uji hipotesis parsial atau uji $\mathrm{t}$ di atas, maka dapat disimpulkan bahwa komunikasi mempunyai pengaruh yang positif dan signifikan terhadap kinerja karyawan pada PT. Ira Widya Utama Medan.

\section{b. Pengaruh Budaya Organisasi Terhadap Kinerja Karyawan}

Robbins dalam bukunya Torang $(2014: 106)$ berpendapat bahwa budaya oraganisasi merupakan suatu sistem dari makna organisasi/arti bersama yang dianut dari para anggotanya yang membedakan organisasi dari organisasi lainnya. Budaya organisasi dapat juga dikatakan sebagai kebiasaan yang terus berulang-ulang dan menjadi nilai dan gaya hidup oleh sekelompok individu dalam organisasi yang diikuti oleh individu berikutnya. Hal ini didukung keseluruhan jawaban responden untuk pernyataan dari variabel budaya organisasi terdapat $71,0 \%$ responden yang memilih jawaban sangat setuju dan jawaban setuju. Hal ini menunjukkan bahwa budaya organisasi dalam perusahaan ini dikategorikan baik, sedangkan dari keseluruhan jawaban responden terdapat $11,2 \%$ responden yang memilih 
jawaban tidak setuju. Berdasarkan hasil uji hipotesis parsial atau uji $\mathrm{t}$ di atas, maka dapat disimpulkan bahwa budaya organisasi mempunyai pengaruh yang positif dan signifikan terhadap kinerja karyawan pada PT. Ira Widya Utama Medan.

\section{c. Pengaruh Kompensasi Terhadap Kinerja Karyawan}

Kompensasi sangat penting bagi karyawan itu sendiri sebagai individu, karena besarnya kompensasi merupakan pencerminan atau ukuran nilai pekerjaan karyawan itu sendiri. Hal ini didukung keseluruhan jawaban responden untuk pernyataan dari variabel kompensasiterdapat $68,1 \%$ responden yang memilih jawaban sangat setuju dan jawaban setuju. Hal ini menunjukkan bahwa kompensasi dalam perusahaan ini dikategorikan baik, sedangkan dari keseluruhan jawaban responden terdapat $13,3 \%$ responden yang memilih jawaban tidak setuju. Berdasarkan hasil uji hipotesis parsial atau uji $\mathrm{t}$ di atas, maka dapat disimpulkan bahwa kompensasi mempunyai pengaruh yang positif dan signifikan terhadap kinerja karyawan pada PT. Ira Widya Utama Medan.

\section{d. Pengaruh Komunikasi, Budaya Organisasi dan Kompensasi Terhadap Kinerja Karyawan}

Komunikasi, budaya organisasi dan kompensasi mempunyai peranan yang sangat penting dalam meningkatkan kinerja karyawan. Hal ini didukung keseluruhan jawaban responden untuk pernyataan dari variabel kinerja karyawan terdapat 66,9\% responden yang memilih jawaban sangat setuju dan jawaban setuju. Hal ini menunjukkan bahwa kinerja karyawan dalam perusahaan ini dikategorikan cukup baik, sedangkan dari keseluruhan jawaban responden terdapat $13,4 \%$ responden yang memilih jawaban tidak setuju. Berdasarkan hasil uji hipotesis simultan atau uji $\mathrm{F}$ di atas, maka dapat disimpulkan bahwa komunikasi, budaya organisasi dan kompensasi mempunyai pengaruh yang positif dan signifikan terhadap kinerja karyawan padaPT. Ira Widya Utama Medan.

\section{KESIMPULAN}

Berdasarkan hasil analisis deskriptif untuk variabel komunikasi, budaya organisasi berada pada kategori baik, variabel kompensasi dan kinerja berada dalam kategori cukup baik pada PT. Ira Widya Utama Medan. Berdasarkan hasil uji t komunikasi mempunyai pengaruh yang positif dan signifikan terhadap kinerja karyawan pada PT. Ira Widya Utama Medan dimana hal ini mengindikasikan bahwa semakin baik komunikasi yang diterapkan oleh pimpinan perusahaan, maka kinerja yang dihasilkan oleh karyawan akan semakin meningkat. Hasil uji $\mathrm{t}$ untuk budaya organisasi mempunyai pengaruh yang positif dan signifikan terhadap kinerja karyawan pada PT. Ira Widya Utama Medan dimana hal ini mengindikasikan bahwa semakin kuat budaya organisasi yang diterapkan oleh pimpinan perusahaan, maka kinerja yang dihasilkan oleh karyawan akan semakin meningkat.Hasil uji t untuk kompensasi mempunyai pengaruh yang positif, dan signifikan terhadap kinerja karyawan pada PT. Ira Widya Utama Medan dimana hal ini mengindikasikan bahwa tinggi kompensasi yang diberikan kepada karyawan akan meningkatkan kinerja karyawan.

Berdasarkan hasil uji F untuk variabel komunikasi, budaya organisasi dan kompensasi mempunyai pengaruh yang positif dan signifikan terhadap kinerja karyawan pada PT. Ira Widya Utama Medan dimana hal ini mengindikasikan bahwa semakin baik komunikasi, semakin kuat budaya organisasi dan semakin tinggi kompensasi yang dirasakan oleh karyawan, maka kinerja karyawan akan semakin meningkat.Hasil perhitungan koefisien determinasi menunjukkan bahwa kontribusi dari variabel komunikasi, budaya organisasi dan variabel kompensasi untuk meningkatkan variabel kinerja karyawan pada PT. Ira Widya Utama Medanadalah sebesar 0,812 atau 81,2\%, sedangkan sisa 0,188 atau 18,8\% \%, dipengaruhi oleh variabel lain yang tidak diteliti oleh penulis di dalam penelitian ini, seperti motivasi kerja, kepemimpinan, lingkungan kerja, kompetensi, komitmen kerja dan lain sebagainya. 


\section{DAFTAR PUSTAKA}

Appley Oey Ling Lee, 2010, Pengantar Manajemen. Jakarta. Salemba Empat Arikunto, Suharsimi, 2010. Prosedur Penelitian Suatu Pendekatan Praktik, Edisi Revisi, Penerbit Rineka Cipta, Jakarta.

Bangun Wilson, 2012. Manajemen Sumber Daya Manusia, Penerbit Erlangga, Jakarta.

Gibson, James L. et al. 2012. Organizations Behavior, Structure, Processes, Fourteenth Edition, Publisher McGraw-Hill Irwin, New York.

Hasibuan, Malayu S.P., 2012. Manajemen Sumber Daya Manusia, Edisi Revisi, Cetakan Kelima Belas, Penerbit PT. Bumi Aksara, Jakarta.

Ismail Nawawi Uha, 2015. Budaya Organisasi Kepemimpinan dan Kinerja, Penerbit Prenadamedia Group, Jakarta.

Ivancevich John M.,dkk. 2012. Perilaku dan Manajemen Organisasi, Jilid 2 Edisi Ketujuh, Alih Bahasa Dharma Yuwono, Penerbit Erlangga, Jakarta.

Luthans, Fred, 2011. Organizational Behavior: An Evidence-Based Approach, Twelfth Edition, Publisher McGraw-Hill Irwin, New York.

Mangkunegara, A.A.A.P., 2011. Manajemen Sumber Daya Manusia Perusahaan,Cetakan Kesepuluh, Penerbit PT. Remaja Rosdakarya, Bandung.

Mathis, Robert L., and Jackson, John H., 2011. Human Resource Management, Thirteenth Edition, Publisher South-Western Cengage Learning, UnitedStates of America.

McShane, Steven L. \& Von Glinow, Mary Ann, 2008. Organizational Behavior (fourth edition).USA : McGRAW-Hill International.

M. Syamsul Ma'arif dan Linda Kartika, 2012. Manajemen Kinerja Sumber Daya Manusia, Penerbit IPB Press, Bogor.

Mohammad Faisal Amir, 2015. Memahami Evaluasi Kinerja Karyawan konsep dan Penilaian Kinerja Perusahaan, Penerbit Mitra Wacana Media, Jakarta

Riduwan, 2012. Belajar Mudah Penelitian untuk Guru, Karyawan, dan Peneliti Pemula, Penerbit CV. Alfabeta, Bandung.

Robbins, Stephen P., and Coulter, Mary.r, 2012. Management, Eleventh Edition, Publisher Prentice Hall, New Jersey.

Robert L. Mathis dan John H.Jackson, 2009. Human Resource Management. Penerjemah : Diana Angelica, Edisi Kesepuluh, Penerbit Salemba Empat, Jakarta.

Sinambela Lijan Poltak, 2016. Manajemen Sumber Daya Manusia, Penerbit PT. Bumi Aksara, Jakarta.

Sugiyono, 2014. Metode Penelitian Administrasi dilengkapi dengan Metode R\&D, Cetakan Kedua Puluh Dua, Penerbit CV. Alfabeta, Bandung.

Sunyoto, Danang. 2013. Manajemen Sumber Daya Manusia. Edisi Pertama, Yogyakarta: Caps. Syamsir Torang, 2014. Organisasi dan Manajemen, Penerbit Alfabeta, Bandung.

Wibowo, 2010. Manajemen Kinerja. Penerbit Raja Grafindo Persada. Jakarta.

Wayne Mondy R.,2008. Manajemen Sumber Daya Manusia, Tr.By Bayu Airlangga, Jilid 1, Edisi 10, Penerbit Erlangga, Jakarta.

Yani, H.M., 2012. Manajemen Sumber Daya Manusia, Penerbit Mitra Wacana Media, Jakarta. 